\title{
PERAN KELEMBAGAAN DALAM MENDUKUNG PROGRAM MINAPOLITAN BUDIDAYA DI KABUPATEN SLEMAN, D.I. YOGYAKARTA
}

\author{
Maharani Yulisti dan Riesti Triyanti \\ Balai Besar Penelitian Sosial Ekonomi Kelautan dan Perikanan \\ JI. KS. Tubun Petamburan VI Jakarta 10260 \\ Telp. (021) 53650162, Fax. (021)53650159 \\ Diterima 17 Jan 2012- Disetujui 24 Mei 2012
}

\begin{abstract}
ABSTRAK
Pengembangan kawasan minapolitan yang memanfaatkan potensi wilayah dengan memberi peluang pemberdayaan ekonomi masyarakat berbasis perikanan memerlukan sinergitas dari potensi yang ada secara utuh, menyeluruh, berdaya saing dan berkelanjutan. Upaya in memerlukan campur tangan pemerintah dan dukungan masyarakat dalam membangun kelembagaan yang dapat mendukung program minapolitan. Tulisan ini bertujuan untuk mengidentifikasi kelembagaan yang mendukung program minapolitan perikanan budidaya yang ada di Kabupaten Sleman D.I. Yogyakarta. Kelembagaan formal yang ada di Kabupaten Sleman, D.I. Yogyakarta diantaranya lembaga penguatan modal (Unit Pelayanan Pengembangan/UPP Bidang Perikanan, Koperasi Simpan Pinjam, Koperasi Unit Desa/KUD, Badan Usaha Kredit Perdesaan/BUKP, lembaga kredit dan Program Nasional Pemberdayaan Masyarakat/PNPM), lembaga penyuluhan dan lembaga perbenihan (Balai Benih Ikan atau BBI). Kelembagaan non formal yang sudah berfungsi baik yang erat kaitannya dengan program minapolitan diantaranya kelembagaan penyedia input, kelembagaan penyedia modal, kelembagaan pelaku usaha (pembudidaya, pembenih, pendeder), kelembagaan pengolah hasil perikanan, kelembagaan pemasaran ikan, serta kelembagaan penyedia informasi dan teknologi. Peran kelembagaan formal dan informal sangat penting untuk kegiatan budidaya perikanan pada level menengah ke bawah diantaranya untuk menstabilkan harga terutama saat pasokan ikan berlebih, pemenuhan kebutuhan modal, input usaha dan sarana produksi ikan.
\end{abstract}

Kata kunci: kelembagaan, minapolitan, perikanan budidaya

Abstract : $\quad$ Role of Institutional on Support of Minapolitan Program of Aquaculture in Sleman District, D.I. Yogyakarta. By: Maharani Yulisti

Implementing of spatial based of marine and fisheries development (locally know as MInapolitan) that use opportunities for community based economic empowerment of fisheries require the synergy of the existing potential in integrated, comprehensive, competitive and sustainable. Government intervention and community supports required to support the Minapolitan program on building of institutions. This paper aimed to identify formal and informal institutional roles in supporting the Minapolitan program of aquaculture in Sleman District, D.I. Yogyakarta. The existing formal institutions in the Sleman District are capital strengthening institutions such as Fisheries Development Services Unit, Savings and Credit Cooperatives, Village Unit Cooperatives, Credit Rural Enterprise, Credit Institutions, and The National Program For Community Empowerment, counseling agencies and institutions germination (Fish Breeding Centers). Non-formal institutions are already functioning well is closely related to the minapolitan program including input providers institution, capital providers institution, business actors institution (farmers, breeders), processing of fishery products institution, fish marketing institutions, and information and technology providers institution. The roles of formal and informal institutions are essential for aquaculture activities in the lower and middle level to stabilize prices especially when an excess supply of fish, capital needs, input of aquaculture and fish production facilities.

Keywords : institutional, minapolitan, aquaculture

\section{PENDAHULUAN}

Minapolitan adalah konsep pembangunan kelautan dan perikanan berbasis wilayah dengan pendekatan dan sistem manajemen kawasan dengan prinsip-prinsip : integrasi, efisien, kualitas, dan akselerasi (Menteri Kelautan dan Perikanan, 2010). Sedangkan menurut Hubeis dan Wasmana (2010), pengertian minapolitan adalah kawasan pengembangan ekonomi berbasis perikanan yang dikembangkan secara bersama oleh pemerintah, swasta, dan organisasi non pemerintah untuk menciptakan kondisi yang lebih baik untuk pertumbuhan ekonomi lokal dan penciptaan lapangan kerja pada wilayah yang ditetapkan.
Dalam Undang-Undang Nomor 26 tahun 2007 tentang Penataan Ruang dijelaskan wilayah ruang merupakan kesatuan geografis beserta segenap unsur yang terkait kepadanya yang batas dan sistemnya ditentukan berdasarkan aspek administratif dan atau aspek fungsional. Komponen-komponen wilayah mencakup komponen biofisik alam, sumberdaya buatan (infrastruktur), manusia serta bentuk-bentuk kelembagaan.

Secara empirik, keberhasilan program yang berbasis pada pendekatan wilayah sangat bergantung pada kelembagaan pengelolaan yang didefinisikan sekumpulan jaringan dari relasi sosial yang melibatkan 
orang-orang tertentu, memiliki tujuan tertentu, memiliki aturan dan norma, serta memiliki struktur. Untuk mendukung kebijakan kementerian kelautan dan perikanan tersebut, maka perlu dilakukan penguatan kelembagaan. Kelembagaan merupakan sekumpulan jaringan dari relasi sosial yang melibatkan orang-orang tertentu yang memiliki tujuan tertentu, yang diatur oleh aturan dan norma, serta memiliki struktur.

Kabupaten Sleman memiliki sumberdaya perikanan yang cukup besar sehingga perlu dilakukan pengelolaan sumberdaya melalui penguatan kelembagaan yang ada. Potensi perikanan budidaya seperti ikan nila, lele dan udang galah perlu dikembangkan guna mendukung program minapolitan. Peran kelembagaan yang ada di Kabupaten Sleman perlu dikaji guna mengetahui dukungannya terhadap program minapolitan perikanan budidaya. Pemanfaatan potensi wilayah memberi peluang optimalisasi pemberdayaan ekonomi masyarakat yang berbasis perikanan dengan mensinergikan berbagai potensi yang ada, utuh dan menyeluruh, berdaya saing, berkelanjutan digerakkan oleh masyarakat dan difasilitasi oleh pemerintah (Bappeda Kabupaten Sleman, 2010).

\section{Peran Kelembagaan dalam Program Minapolitan}

Salah satu lokasi minapolitan budidaya adalah Kabupaten Sleman yang dipusatkan di Kecamatan Berbah dan Kecamatan Ngemplak. Ikan yang dibudidayakan di Kecamatan Berbah meliputi ikan nila, mas, bawal, gurami, lele, tawes, udang galah, lobster. Ikan yang dibudidayakan di Kecamatan Ngemplak adalah ikan nila, karper, gurame, lele, dan ikan koan (grasscarp).

Peran kelembagaan sangat penting dalam kegiatan budidaya pada skala menengah dan kecil. Kelembagaan yang dimaksud adalah kelembagaan formal (memiliki badan hukum) dan kelembagaan informal (berupa kelompok masyarakat). Kelembagaan formal yang sudah terbentuk dan berfungsi baik di Kabupaten Sleman adalah lembaga penguatan modal yaitu Unit Pelayanan
Pengembangan (UPP) bidang perikanan. Lembaga ini bertujuan untuk mengelola bantuan hibah dari pemerintah pusat agar dapat bergulir kepada pelaku usaha perikanan. UPP ini bersifat dinamis dan terbuka pada inovasi yang diharapkan dapat berfungsi sebagai Sentra Pembelajaran dan Pengembangan Minabisnis (SPPM).

Di Kecamatan Berbah terdapat berbagai jenis sarana keuangan. Menurut data monografi Kecamatan Berbah tahun 2009, sarana keuangan tersebut diantaranya Koperasi Simpan Pinjam 1 buah, KUD 1 buah, BUKP 1 buah, lembaga kredit 1 buah, PNPM MP 1 buah dengan total jumlah nasabah sebanyak 903 orang.

Penyuluhan dan bimbingan teknologi minabisnis merupakan kelembagaan formal lainnya di Kabupaten Sleman. Penyuluh berada di bawah tanggung jawab Dinas Perikanan setempat. Sosialisasi penerapan cara budidaya ikan yang baik (good aquaculture practices) terus dilakukan oleh para penyuluh sebagai upaya penyiapan pelaku utama dan pelaku usaha untuk selalu mengutamakan kualitas dan peduli lingkungan dalam budidaya perikanan di era globalisasi. Pengembangan teknologi tepat guna yang cocok di kawasan minapolitan merupakan tujuan utama para penyuluh perikanan dalam melaksanakan tugasnya.

Penyuluh mempunyai pengaruh yang sangat besar dalam mentransfer teknologi dan informasi yang dibutuhkan oleh pembudidaya ikan. Penyuluh di Kabupaten Sleman mempunyai potensi yang cukup baik dalam memberikan informasi dan teknologi tersebut, namun mereka memiliki banyak kendala dalam kapasitasnya. Sarana bimbingan dan penyuluhan yang berlokasi di Kabupaten Sleman antara lain:

- Balai Penyuluhan Pertanian, Perikanan dan Kehutanan (BP3K) yang berfungsi sebagai klinik konsultasi, yaitu sebagai sumber informasi, tempat percontohan dan pusat pemberdayaan masyarakat dalam pengembangan usaha perikanan yang lebih efisien dan menguntungkan

Tabel 1. Keragaan Balai Benih Ikan (BBI) di Kabupten Sleman, D.I. Yogyakarta, Tahun 2009.

\begin{tabular}{clcc}
\hline \multirow{2}{*}{ No Uraian } & \multicolumn{2}{c}{ Kecamatan } \\
\cline { 3 - 4 } & & Berbah & Ngemplak \\
\hline 1 & Jumlah BBI & 1 & 1 \\
2 & Jumlah Personil & 4 & 5 \\
3 & Luas Areal & & 10.000 \\
& Total & 10.000 & 3.800 \\
& Kolam & 8.000 & Oktober-Mei \\
4 & Bulan Produktif & Oktober-Mei & - \\
5 & Bulan Kurang Produktif & Juli-september & Bawal, Patin \\
\hline
\end{tabular}

Sumber: Dinas Pertanian, Perikanan dan Kehutanan Kabupaten Sleman (2010) 
- Balai Benih Ikan (BBI) yang berfungsi sebagai tempat konsultasi teknologi perikanan, sekaligus sumber penghasil benih ikan unggul untuk memenuhi kebutuhan pembudidaya ikan (Gambar 1).

S e I a n j u t n y a $\mathrm{k}$ e l e $\mathrm{m}$ b a g a a $\mathrm{n}$ penyedia modal, para pembudidaya dapat mengakses modal melalui kelompok pembudidaya atau koperasi. Rata-rata pembudidaya tidak berani mengambil risiko untuk mengagunkan sertifikat tanah atau kolam ikannya

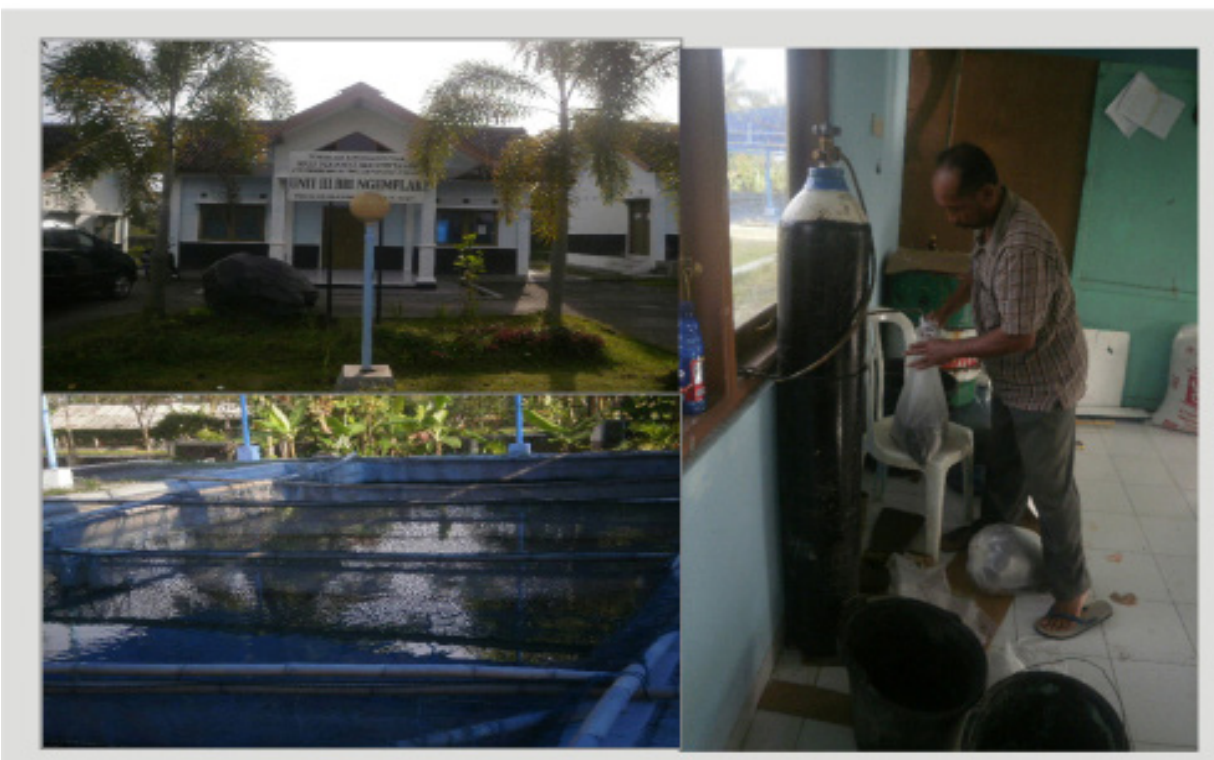

Gambar 1. Balai Benih Ikan (BBI) dan Fasilitas Pembenihan di Kecamatan Ngemplak Sumber : Dokumentasi Pribadi, 2011 ke bank. Di beberapa lokasi minapolitan, kelembagaan penyedia modal selain bank adalah kelembagaan yang dibentuk swadaya masyarakat untuk mengelola uang hibah/bergulir dari pemerintah. Uang tersebut dikelola agar dapat dimanfaatkan oleh seluruh pembudidaya secara bergulir. Uang tersebut meskipun hibah namun tetap harus dikembalikan agar yang lain mendapat kesempatan yang sama dalam pinjaman modal usaha budidaya. Keterbatasan modal usaha yang dimiliki oleh pembudidaya menjadi kendala untuk keberlangsungan usaha budidaya itu sendiri khususnya untuk biaya pemenuhan pakan ikan.

Sebagian besar pembudidaya ikan di Kabupaten Sleman memiliki kelompok sebagai wadah untuk memecahkan permasalahan-permasalahan yang dihadapi dalam usaha budidaya ikan. Selain itu kelompok pembudidaya ini juga berusaha mengembangkan wadah tersebut sebagai sarana usaha

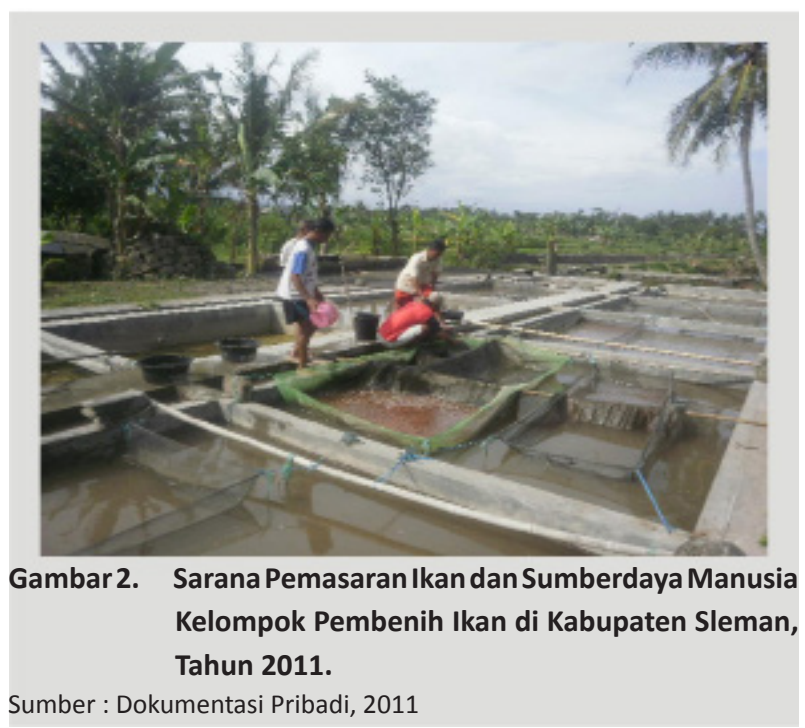

pemasaran ikan dan penyediaan input budidaya ikan. Pemasaran ikan dalam kelompok diharapkan dapat membuat harga ikan stabil di wilayah tersebut karena harga tidak mudah dipermainkan oleh pedagang perantara atau pedagang pengumpul.

Kelembagaan pemasaran mempunyai fungsi yang sangat penting terutama pada saat terjadi kelebihan pasokan (over supply). Penyediaan input budidaya ikan dalam kelompok diharapkan dapat mempermudah pembudidaya untuk mendapatkan input usaha. Permasalahan utama pembudidaya di Kabupaten Sleman adalah jeratan hutang dari pedagang perantara/ pengumpul yang dapat menyediakan input budidaya ikan sehingga membuat pembudidaya harus menjual ikannya kepada mereka dengan harga yang sudah ditentukan.

Beberapa syarat agar kegiatan kelompok usaha berjalan efektif dan efisiennya dalam mendukung program minapolitan di Kabupaten Sleman, diantaranya:

1. Pertemuan rutin kelompok, dengan pendekatan kelompok yang mengacu pada keberadaan tempat tinggal dan lokasi budidaya yang relatif berdekatan memiliki tingkat pertemuan rutin kelompok yang tinggi;

2. Kehadiran dalam pertemuan rutin kelompok yang akan berdampak terhadap tingkat penguatan kapasitas dalam organisasi kelompok serta berjalannya proses dinamika kelompok;

3. Keputusan-keputusan dalam pertemuan kelompok yang bersifat mengikat atau anjuran sehingga menjadi acuan dalam ketentuan organisasi kelompok dalam upaya membangun profil kelompok yang baik. Sikap proaktif anggota dalam pembahasan masalah dan pengembangan informasi akan menentukan kualitas keputusan 
penting yang diambil oleh kelompok;

4. Kerjasama antar anggota dalam kelompok, akan terjadi interaksi positif dan dapat direalisasikan secara baik dengan kondisi bahwa pertemuan rutin dilakukan, tingkat kehadiran anggota cukup tinggi, dan keputusan yang bersifat mengikat dipatuhi dengan baik;

5. Peranan pendamping manajemen, dengan kualitas yang sudah diperhitungkan baik dalam aspek teknis budidaya maupun manajemen usaha budidaya yang dilakukan secara rutin dan sistematis;

6. Peranan pendamping lokal (Tenaga Pendamping Teknologi atau TPT), yang memiliki konsistensi tinggi untuk tetap menjalankan fungsi pembinaan secara baik bagi kelompok budidaya ikan;

7. Kemandirian kelompok, akan terbentuk dengan baik bila pencapaian tujuan dikembangkan melalui pengelolaan organisasi kelompok secara baik;

8. Profil kelompok, merupakan pendekatan yang baik untuk menilai eksistensi kelompok pembudidaya secara nyata. Bentuk sederhana profil kelompok adalah Anggaran Dasar/Anggaran Rumah Tangga (AD/ART) kelompok dengan memberikan informasi detil dari setiap kegiatan usaha kelompok;

9. Catatan pembukuan usaha, merupakan buku catatan detil dari setiap aspek usaha budidaya yang dilakukan, misalnya jenis ikan yang ditebar, jumlah dan ukuran ikan yang ditebar, jumlah dan ukuran jenis ikan hasil pembenihan, masa produksi budidaya, jenis pakan, jumlah panen, harga jual per jenis ikan (data teknis budidaya);

10. Penyelenggaraan kegiatan usaha simpan pinjam, berasal dari simpanan wajib maupun simpanan sukarela yang akan meningkatkan aset kelompok untuk tujuan pengembangan usaha anggota dengan prosedur peminjaman dan pengembalian pinjaman yang telah diatur dan disepakati bersama. Pinjaman ini dapat berupa uang maupun barang (pakan, pelet, induk dan benih);

11. Outlet pemasaran produksi hasil panen, merupakan fasilitas terpadu yang berbentuk bangunan tertutup atau semi tertutup yang berfungsi untuk kegiatan pemasaran produk dengan berbagai fasilitas penunjang;

12. Catatan potensi pasar, mengacu pada nama pembeli baik secara perorangan maupun kelompok yang dicatat secara sederhana dalam buku transaksi/pesanan.

Tujuan dibentuknya kelompok usaha budidaya ini diantaranya adalah:

1. Mengangkat ekonomi masyarakat desa dan sekitarnya khususnya yang tergabung dalam kelompok

2. Meningkatkan kualitas dan kuantitas produk ikan

3. Memberi kemudahan pada anggota dalam pemasaran hasil perikanan

4. Menumbuhkembangkan potensi perikanan

5. Meningkatkan pengetahuan dan keterampilan baik anggota kelompok maupun masyarakat sekitarnya.

\section{Profil Kelembagaan Terkait Program Minapolitan}

Data profil kelompok pembudidaya ikan tahun 2009 (Tabel 2) menunjukkan bahwa jumlah kelompok di Kecamatan Berbah adalah 18 kelompok yang terdiri dari berbagai tingkatan yaitu pemula, lanjut, madya dan utama, dengan anggota sebanyak 467 orang. Jumlah kelompok pembudidaya di Kecamatan Ngemplak adalah 25 kelompok yang terdiri dari 764 orang anggota.

Pedagang perantara atau pedagang pengumpul

Tabel 2. Profil Kelompok Pembudidaya Ikan Tahun 2009.

\begin{tabular}{clrr}
\hline \multirow{2}{*}{ No } & \multicolumn{1}{c}{ Uraian } & \multicolumn{2}{c}{ Kecamatan } \\
\cline { 3 - 4 } & & Berbah & Ngemplak \\
\hline 1 & Jumlah Kelompok & 18 & 25 \\
& - Pemula & 10 & 12 \\
& - Lanjut & 4 & 9 \\
& - Madya & 4 & 2 \\
& - Utama & 0 & 2 \\
\hline 2 & Jumlah Anggota (orang) & 467 & 764 \\
\hline 3 & Luas Lahan (m ${ }^{2}$ ) & 252.770 & \\
\hline 4 & Produksi Tahun 2009 & & 707.500 \\
& - Konsumsi (Kg) & 382.085 & 1.172 .500 \\
\hline
\end{tabular}

Sumber: Dinas Pertanian, Perikanan dan Kehutanan Kabupaten Sleman (2010) 
di Kabupaten Sleman biasanya melakukan usahanya secara kelompok. Beberapa pedagang perantara kecil terikat pada salah satu pedagang besar baik di dalam kawasan itu sendiri maupun di luar kota. Ikatan tersebut biasanya dilakukan melalui modal yang diberikan oleh pedagang besar atau berupa kekerabatan. Namun tidak sedikit pedagang kecil melakukan transaksi terhadap pedagang besar berdasarkan harga yang ditawarkan.

Jumlah pasar umum yang ada di Kecamatan Berbah sebanyak empat unit dan pasar semi permanen empat unit. Diantara pasar tersebut adalah Pasar Tanjungtirto dan pasar rintisan dari proyek Pendukung Pemberdayaan Masyarakat dan Pemerintah Daerah (P2MPD) yang memungkinkan dimanfaatkan untuk pemasaran hasil-hasil perikanan. Disamping pasar umum, terdapat juga pasar khusus yakni pasar ikan kelompok bernama Nila Makmur yang berlokasi di Karangasem, Sendangtirto, Berbah.

Pasar tersebut dikelola oleh Kelompok Pembudidaya Ikan (KPI) Nila Makmur. Potensi kelembagaan lainnya di Kecamatan berbah adalah empat buah rumah makan khas ikan, tiga orang pengusaha/pedagang pengentas ikan dan delapan unit usaha pemancingan (Tabel 3).

Pasar ikan kelompok yang ada di Kecamatan
Berbah bernama Nila Makmur, dengan pelayanan setiap hari dari pagi hingga sore hari. Fasilitas pelayanan berupa bak penampungan dan oksigen. Volume perdagangan optimal terjadi pada bulan Oktober sampai dengan Maret, sedangkan perdagangan kurang optimal terjadi pada bulan Mei sampai dengan September setiap tahunnya. Ikan berasal dari kelompok dan petani sekitarnya dengan mayoritas konsumen berasal dari lingkup DI. Yogyakarta. Sistem pengelolaan pasar dilakukan oleh Seksi Pemasaran Kelompok.

Pasar ikan yang ada di Kecamatan Ngemplak berjumlah enam unit usaha. Pasar tersebut rata-rata melakukan pelayanan setiap hari tergantung pasokan ikan yang ada. Fasilitas pelayanan berupa plastik wadah ikan, oksigen, dan jasa pengantaran ke tempat tujuan dengan armada pengangkut yang dimiliki. Volume perdagangan optimal terjadi pada bulan November sampai dengan April, sedangkan perdagangan kurang optimal terjadi pada bulan Mei sampai dengan Oktober setiap tahunnya. Ikan yang dijual berasal dari kelompok dan petani sekitarnya, dengan konsumen kebanyakan berasal dari petani karamba dan jaring apung lingkup DIY dan Jawa Tengah. Sistem pengelolaan pasar dilakukan oleh kelompok sesuai AD/ART kelompok.

Fasilitas penunjang lainnya adalah usaha

Tabel 3. Profil Pasar Ikan Kelompok di Kabupaten Sleman Tahun 2009.

\begin{tabular}{clcc}
\hline \multirow{2}{*}{ No } & \multicolumn{1}{c}{ Uraian } & \multicolumn{2}{c}{ Kecamatan } \\
\cline { 3 - 4 } & & Berbah & Ngemplak \\
\hline 1 & Jumlah Pasar & 1 & 6 \\
2 & Komoditas Dominan & Nila, Bawal, & Karper, Nila, \\
& & Gurami, Lele & Grasscarp, Lele \\
3 & Volume Optimal & & \\
& $-\quad$ Benih (Ekor/bulan) & 55.000 & 22.250 .000 \\
& $-\quad$ Konsumsi (Kg/bulan) & 900 & 35.750 \\
4 & Volume Kurang Optimal & & 12.000 .000 \\
& $-\quad$ Benih (Ekor/bulan) & 25.000 & 15.250 \\
\hline
\end{tabular}

Sumber: Dinas Pertanian, Perikanan dan Kehutanan Kabupaten Sleman (2010)

Tabel 4. Profil Pedagang Pengecer Ikan di Kabupaten Sleman Tahun 2009.

\begin{tabular}{|c|c|c|c|}
\hline \multirow{2}{*}{ No } & \multirow{2}{*}{ Uraian } & \multicolumn{2}{|c|}{ Kecamatan } \\
\hline & & Berbah & Ngemplak \\
\hline 1 & Jumlah Pedagang & 4 & 6 \\
\hline \multirow[t]{2}{*}{2} & Jumlah Tenaga Kerja & 15 & 20 \\
\hline & Volume Perdagangan & & \\
\hline \multirow[t]{2}{*}{3} & - $\quad$ Rata-rata (Kg/minggu) & 15.200 & 13.000 \\
\hline & - $\quad$ Maksimum (Kg/minggu) & 20.000 & 21.000 \\
\hline 4 & Jenis Ikan yang diperdagangkan & $\begin{array}{l}\text { Nila, Bawal, } \\
\text { Gurami, Lele }\end{array}$ & Bawal, Nila, Lele \\
\hline
\end{tabular}

Sumber: Dinas Pertanian, Perikanan dan Kehutanan Kabupaten Sleman (2010 
Tabel 5. Profil usaha Pemancingan Ikan di Kabupaten Sleman Tahun 2009.

\begin{tabular}{|c|c|c|c|}
\hline \multirow{2}{*}{ No } & \multirow{2}{*}{ Uraian } & \multicolumn{2}{|c|}{ Kecamatan } \\
\hline & & Berbah & Ngemplak \\
\hline 1 & Jumlah Pemancingan & 8 & 3 \\
\hline \multirow[t]{4}{*}{2} & Jumlah Tenaga Kerja & 14 & 8 \\
\hline & Rata-rata pemancing (Orang/hari) & & \\
\hline & - $\quad$ Hari biasa & 105 & 35 \\
\hline & - Hari libur & 310 & 85 \\
\hline \multirow[t]{3}{*}{3} & Kebutuhan ikan & & \\
\hline & - Hari biasa & 105 & 90 \\
\hline & - Hari libur & 395 & 310 \\
\hline
\end{tabular}

Sumber: Dinas Pertanian, Perikanan dan Kehutanan Kabupaten Sleman (2010)

pemancingan ikan. Usaha pemancingan ikan di Kabupaten Sleman memiliki peluang bisnis yang cukup menjanjikan. Disamping karena populasi penduduknya yang cukup tinggi, Kabupaten Sleman juga merupakan daerah sentra pariwisata serta kota pelajar dimana masyarakatnya membutuhkan tempat untuk rekreasi keluarga serta kuliner masakan ikan. Hal ini terlihat dari jumlah pengunjung pemancingan pada hari libur lebih banyak dibandingkan hari biasa yang hanya mencapai sepertiga pengunjung saja (Tabel 6). untuk menstabilkan harga terutama saat pasokan ikan berlebih, pemenuhan kebutuhan modal, input usaha dan sarana produksi ikan sehingga pembudidaya ikan tidak perlu meminjam uang kepada pedagang (jaminannya adalah penjualan ikan kepada pedagang tersebut dengan harga yang telah ditentukan olehnya). Bila hal ini terjadi maka ekonomi rumah tangga pun meningkat sehingga perekonomian di lokasi minapolitan pun dapat tumbuh karena kesejahteraan meningkat.

Tabel 6. Profil Rumah Makan Khas Ikan di Kabupaten Sleman Tahun 2009.

\begin{tabular}{|c|c|c|c|}
\hline \multirow{2}{*}{ No } & \multirow{2}{*}{ Uraian } & \multicolumn{2}{|c|}{ Kecamatan } \\
\hline & & Berbah & Ngemplak \\
\hline 1 & Jumlah Rumah Makan & 4 & 4 \\
\hline 2 & Jumlah Tenaga Kerja & 18 & 44 \\
\hline 3 & Rata-rata Pembeli (Orang/minggu) & 560 & 905 \\
\hline 4 & Rata-rata Kebutuhan ikan (Kg/bulan) & 1.350 & 3.000 \\
\hline
\end{tabular}

Sumber: Dinas Pertanian, Perikanan dan Kehutanan Kabupaten Sleman (2010)

Pada usaha budidaya ikan di Kabupaten Sleman, kelembagaan pengolah ikan kurang berkembang. Hal ini terjadi karena sebagian besar produk perikanan hasil budidaya merupakan ikan hidup dan segar. Ada sebagian kecil hasil budidaya diolah, namun biasanya dilakukan oleh perusahaan swasta atau pengusaha kecil skala rumah tangga.

\section{KESIMPULAN DAN SARAN}

Peningkatan produksi perikanan melalui program minapolitan perlu didukung oleh kelembagaan yang ada. Fungsi kelembagaan dibutuhkan untuk membantu pelaku usaha budidaya ikan agar lebih berdaya saing sehingga harga ikan lebih baik dan lebih adil bagi pelaku usaha. Fungsi kelembagaan tersebut diantaranya
Saran terkait dengan beberapa permasalahan kelembagaan di atas, maka beberapa upaya yang dapat dilakukan diantaranya adalah penguatan kelembagaan pembudidaya ikan agar lebih berkembang. Kelembagaan tidak hanya sebagai wadah pemecahan masalah dan pencarian solusi mengenai budidaya ikan, namun juga dapat dikembangkan sebagai wadah pemasaran ikan dan penyedia input budidaya. Hal ini dilakukan untuk memperpendek rantai pasar ikan sehingga ikan memiliki daya saing yang lebih baik. Rantai pasar yang pendek dapat meyebabkan harga ikan lebih bersaing. Penguatankelembagaan inidapatjuga dilakukan dengan pembentukan koperasi pembudidaya ikan untuk mempermudah akses modal dan sarana produksi ikan serta input budidaya. 
Penguatan kelembagaan penyuluh dengan meningkatkan kuantitas maupun kualitas penyuluh. Peningkatan kuantitas penyuluh dilakukan dengan penambahan jumlah penyuluh di setiap daerah sehingga setiap desa memiliki penyuluh. Peningkatan kualitas penyuluh dilakukan dengan pendidikan dan pelatihan teknis yang dapat digunakan langsung di lapangan. Peningkatan upah/honor penyuluh dapat meningkatkan kualitas kerja penyuluh, dimana selama ini honor penyuluh sangat kecil dibandingkan dengan intensitas kerjanya yang tinggi serta harus ke pelosok daerah. Penyuluh juga harus dipilih berdasarkan dedikasi mereka terhadap pembangunan ekonomi berkelanjutan di lokasi minapolitan tersebut.

Penguatan kelembagaan pengolahan produk ikan, dengan meningkatkan kapasitas istri pembudidaya ikan. Penyuluh perikanan harus aktif memberikan teknologi pengolahan yang didukung oleh hasil penelitian tepat guna. Disamping memberikan nilai tambah terhadap produk perikanan, penuluh juga harus memberdayakan istri pembudidaya sehingga dapat memiliki mata pencaharian untuk membantu ekonomi rumah tangganya. Pembentukan kelompok pengolah dilakukan untuk memberdayakan modal dan alat pengolahan ikan untuk dikelola secara bersama-sama.

Teknologi pengolahan yang mudah dan tepat guna untuk istri pembudidaya diantaranya pengolahan kerupuk ikan, dendeng ikan, ikan asin, makanan olahan (nugget, bakso, otak-otak), terasi, dan pengasapan ikan. Abon ikan kurang diminati karena sulit dalam pemasarannya. Selain teknologi pengolahannya, diperlukan juga pelatihan mengenai penggunaan alatalat produksi seperti alat pengepakan, alat pemotong bahan kerupuk.

Kebijakan memperpendek rantai pasar dengan memperhatikan titik inefisiensi pada rantai tersebut. Inefisiensi terjadi bila pada satu titik rantai tidak memberikan nilai tambah pada produk tersebut namun memberikan penambahan harga pada produknya sehingga ikan kurang berdaya saing. Untuk mengetahui terjadinya inefisiensi dapat dilakukan dengan riset value chain analysis.

\section{DAFTAR PUSTAKA}

Badan Perencanaan Pembangunan Daerah Kabupaten Sleman, 2010. Laporan Akhir Penyusunan Masterplan Minapolitan Kabupaten Sleman.

Balai Besar Riset Sosial Ekonomi Kelautan dan Perikanan. 2010. Minapolitan dari Konsep Menuju Implementasi. Jakarta.

Dinas Pertanian, Perikanan dan Kehutanan Kabupaten Sleman. 2009. Profil Perikanan Sleman.

Hartono, Tjahyo Tri dan Taryono Kodiran. 2010. Penguatan Kelembagaan untuk Peningkatan Keberhasilan Usaha dalam Mendukung Program Nasional Pemberdayaan Masyarakat (PNPM) Mandiri Kelautan dan Perikanan (Studi Kasus di Kabupaten Sukabumi, Jawa Barat). Bunga Rampai Hasil Riset: Penguatan Kelembagaan dalam Rangka Pengembangan Usaha dan Pengelolaan Sumberdaya Perikanan. Balai Besar Riset Sosial Ekonomi Kelautan dan Perikanan. Jakarta.

Hubeis, A.V.S dan Wasmana, P. 2010. Strategi Komunikasi Pemberdayaan Masyarakat Melalui Minapolitan. Makalah disampaikan pada Seminar Membangun Minapolitan Berbasis Masyarakat, IPB-Bogor 25 Maret 2010.Bogor.

Menteri Kelautan dan Perikanan. 2010. Revolusi Biru dan Program Nasional Minapolitan. Makalah disampaikan pada Seminar Membangun Minapolitan Berbasis Masyarakat, IPB-Bogor 25 Maret 2010.Bogor. 